\title{
Ernesto Guevara: soldado y soldador del mundo
}

\author{
Ernesto Guevara: Soldier and Solder of the World
}

\section{Claudia GILMaN}

UBA CONICET · http://soypielroja.com

Profesora de la Universidad de Buenos Aires e investigadora de CONICET. Ha publicado numerosos artículos sobre literatura argentina y latinoamericana, especialmente sobre la relación entre cultura y política en los años sesenta y setenta. Sobre ese tema es su libro ya clásico Entre la pluma y el fusil. Debates y dilemas del escritor revolucionario en América Latina (2003). Ha publicado, además, la novela Preciosas Cautivas (1993), en colaboración con Graciela Montaldo.

Resumen: El artículo analiza la figura del Che Guevara como icono de un tiempo y de una época que resuena en el presente. ¿Qué enseña la vigencia del Che? ¿Qué lo deja en estado de apertura?¿En qué agenciamientos o memorias se funda la obcecada durabilidad de la querida presencia?

Palabras clave: Che Guevara, Revolución Cubana, secularización irrealizada.
Abstract: The article analyzes Che Guevara as an icon of a time and an epoch which still echoes in our present. What does reveal its actuality? What does keep its image in a state of openness? The article shows the continuity between some religious paradigms and the political images of Che Guevara.

Key words: Che Guevara, Cuban Revolution, Secularization. 
Cornelius Castoriadis (1997) advierte que hemos dedicado muchos esfuerzos a demostrar que el mundo está fragmentado. Sin embargo, nos recuerda, no se cae a pedazos. Reflexionar sobre ese hecho, propone, es una de las principales tareas de la filosofía actual. Si cada día sabemos más sobre el Universo, gracias a los avances de las ciencias que lo estudian, no debe ser imposible que tratemos, desde otras ciencias, de explicar el mundo, y cómo y por qué se sostiene.

Si un extraterrestre visitara la Tierra y se interesara en averiguar quiénes fueron los hombres más influyentes de la historia contemporánea, seguramente se toparía con Ernesto Guevara de la Serna, cuyo retrato es el más reproducido del mundo en todo tipo de soportes. ¿Qué enseña la vigencia del Che? ¿Qué lo deja en estado de apertura? ¿En qué agenciamientos o memorias se funda la obcecada durabilidad de la querida presencia?

En los años sesenta y setenta (como consecuencia de transformaciones que el mundo experimentó tras la Segunda Guerra Mundial) una parte de los habitantes del planeta creía que se aproximaba una enorme mutación de índole específicamente política y de signo socialista. Vistas las cosas desde hoy, aquella expectativa, tal como fue formulada, parece el non plus ultra de la ironía: la vislumbrada crisis terminal del capitalismo resultó ser no sólo una ilusión sino hasta una de las más equivocadas predicciones (Jameson, 1997).

Sin embargo, y por ejemplo, el pasaje de la Grafosfera a la Videosfera, la consolidación sin precedentes de una cultura de masas y la globalización (además de los movimientos de las minorías, la reivindicación de los derechos a las diferencias), característicos de nuestra actualidad, son procesos para los cuales la energía revolucionaria, internacionalista, igualitaria y atenta al rol de los medios en la vida pública fue imprescindible.

Guevara es la figura emblemática de esos años en los que la revolución mundial parecía ponerse en marcha desde la locomotora del Tercer Mundo (Gilman, 2003). Y si el futuro que se anunciaba estuvo lejos de lo previsto, es decir, fue lo que se clausuró entonces, habrá que averiguar cómo y por qué la vida y la trágica muerte del Che en Bolivia quedaron a salvo de las clausuras de esa época y la traspasaron como un legado que sigue siendo motivo de interrogaciones en nuestras nuevas coordenadas epocales.

El Che se sostiene y sostiene. Está atravesado por elementos vivos de culturas arcaicas, al tiempo que es el máximo emblema del nuevo tipo de cultura que Margaret Mead denomina 'prefigurativa', de la que se espera que todo el conocimiento proceda de los jóvenes y no de los pares o los mayores; dicho en otros términos, aquella que pone en crisis los lazos pedagógicos y procesos de aprendizaje sobre los que se apoyaban las culturas anteriores, haciendo estallar la comprensión y la experiencia de lo generacional.

En conferencias dictadas en 1969, la antropóloga comparte creencias de su tiempo cuando afirma: "Se está produciendo una honda conmoción en las relaciones entre los fuertes y los débiles, los poseedores y los desposeídos, los adultos y los jóvenes”(Mead, 1971: 23). Es significativo que lo que 
define a esos nuevos jóvenes para Mead es su rechazo a la idea de un cambio ordenado o evolutivo (1971: 115). La afirmación parece describir el pensamiento y la acción del Che, signados por la urgencia transformadora.

La descripción del hombre futuro de Mead también esboza, sin mencionarlo, la imagen y el nombre invocados como ejemplo en revueltas, manifestaciones y luchas que se sucedieron en el mundo: Che. Por otra parte, el ideal guevariano del 'hombre nuevo' y su voluntad ejemplificadora de encarnarlo él mismo, en un período donde la apelación a la novedad fue central, también explica en parte su estado de apertura y su destino en la transición epocal.

El Che sobrevive también a la caída del muro de Berlín, que pone fin, según Eric Hobsbawm (1995), al siglo XX. Esa vigencia, si bien no desafía totalmente las provocativas hipótesis de Bruno Latour (2007) según las cuales, la civilización occidental nunca ha sido verdaderamente moderna, pone en duda el hito del ‘milagroso año 1989’ y la desaparición del socialismo real en la ex URSS, que está en el centro de la periodización de Latour y que le permite fundamentar parte de sus argumentos .

La mercantilización no opera contra el Che ni lo desmiente, ya que ella misma es producto de la impactante versatilidad de la sociedad de consumo, en la que el Che comparte ese destino serializado e industrial con Cristo, Lenin, Mao y la Madre Teresa de Calcuta, entre otros. Lo que importa es por qué el Che es un ícono siempre en disponibilidad. Además, su ingreso al mundo de los objetos es inmediato. El editor Feltrinelli le pidió a Korda la famosa foto del Che con la boina, en 1967, y en Milán, ese mismo año, la hizo estampar en el celebérrimo póster. Muy pronto se fabricaron las camisetas con el rostro del Che tomado de aquella foto. Una de las primeras en usarla fue Angela Davis en una manifestación del Black Power en Nueva York (Fillippi, 2007: 4).

¿La perduración tiene que ver con lo que no se clausura o con lo que quizás nunca se clausuró? La apertura del Che remite tanto al futuro como al pasado. La presencia de Guevara en la cultura es un dato que permite estudiar la larga duración, a partir de las significaciones que adquiere esa vigencia y las presuposiciones históricas que la anudan. Nos permite pensar cómo opera el pasado conocido para producir significaciones culturales. Incluso, como sucede con los textos llamados clásicos, ni siquiera hace falta leerlos para saber que su simple mención implica un ingreso en la lengua común, en la koiné, que da por sentado un significado que funciona como taquigrafía social: dantesco, kafkiano, surrealista, etc.

Guevara condensa, en las significaciones que ha adquirido, en las que se dio para sí mismo y en las que le fueron asociadas, una riqueza explicativa tanto del pasado reciente como del pasado remoto, del presente y, por qué no, del futuro. 
Ejemplo de un nomadismo espacial y temporal incalculables, el Che se mueve en todas las geografías posibles, primero en su país natal y luego por el mundo, en estaciones climáticas, todas singulares, todas memorables. Ese nomadismo comienza desde la infancia y su ímpetu no se detiene con la muerte. Al contrario, se intensifica con ella.

En la topología infinita en el espacio y el tiempo el Che no es de ninguna parte y es de todas. No es de nadie y es de todos, factor crucial de su actual mundanidad. Diluye incluso oposiciones entre Oriente y Occidente a tal punto que obliga a reflexionar sobre qué es Oriente y qué es Occidente, y ese mapa imaginario que, en principio, se funda tanto sobre el universo oriental judeo-cristiano como en la filosofía griega. ${ }^{1}$

Guevara es un nexo privilegiado de transición epocal, porque vivió en el momento climático de la inminencia revolucionaria y en el apogeo de la idealización de la cultura del libro, y se inscribió con naturalidad en el naciente universo de la cultura multimediática y global. La potencia audiovisual, sumada a la tendencia de la imaginación religiosa antropomorfista, lo convierte en un mito poderoso y, muchas veces, sagrado.

Ha marcado profundamente la cultura letrada y también la compleja y masiva cultura de la oralidad secundaria. Walter Ong (1982) llama 'oralidad primaria' a la oralidad de una cultura que carece de todo conocimiento de la escritura o la impresión. Es 'primaria' por el contraste con la 'oralidad secundaria' de la actual cultura de alta tecnología, en la cual se mantiene una nueva oralidad mediante el teléfono, la radio, la televisión y otros aparatos electrónicos.

Guevara emerge a la consideración pública en tiempos privilegiados por nuevas condiciones de fama y celebridad. La televisión y la tecnología de la incipiente era digital permite que los sucesos registrados puedan llegar a través de las imágenes a todo aquel que disponga de un televisor para seguir el pulso de lo que pasa, como lo hacía en su momento el propio Che con su familia, unidos al mundo por la radio, escuchando noticias sobre la guerra civil española.

\footnotetext{
${ }^{1} \mathrm{Al}$ margen, resulta interesante cómo el pagano Platón hizo que Sócrates consiguiera proseguir su reflexión sobre la justicia y edificara la República, logrando que el interlocutor aceptara convenir con el filósofo -sin ninguna objeción- la premisa de que, existan o no los dioses, "la divinidad es buena".
} 


\section{Fama}

No se os haga tan amarga

la batalla temerosa que esperáis,

pues otra vida más larga

de fama tan glorïosa acá dexáis.

Jorge Manrique. Coplas a la muerte de su padre.

Ernesto Guevara de la Serna se va de la Argentina en una búsqueda personal sin precedentes. ${ }^{2}$ En el camino que lo lleva en varias etapas hasta la culminación de su más que climática vida y que llena con esa presencia imponente de la que sus conocidos han dado reiterado testimonio, adquiere cierta notoriedad. No era tan habitual por entonces para los habitantes de ningún lugar eso de ver 'viajeros' sin destino. Es así que Guevara sale en fotos de periódicos locales como una curiosidad, consigue diversos empleos (futbolista, fotógrafo, médico, marinero mercante, etc.) y no resulta una figura indiferente a las personas con las que interactúa. En ese camino, así como llega, siempre se va. Se despide todo el tiempo de la gente al paso con la que socializa, los enfermos que cura, los futbolistas con los que juega como profesional, los médicos colegas con los que intercambia ideas. Le acontece estar en Guatemala cuando los militares deponen al presidente Arbenz; se reúne con ministros, embajadores, futuros presidentes, diplomáticos. Por sus lazos de familia es un joven con rápido acceso a los más altos niveles en casos de necesidad. Pero también se reúne con leprosos, mineros y conspiradores. En México conoce a Fidel Castro y se embandera tras la causa del cubano.

Pronto se oirá hablar a los cuatro vientos de que ese hombre mugriento y rotoso partió de su país, a finales de la década de 1950, cuando los primeros reportajes en la Sierra Maestra sorprendan, entusiasmen o preocupen a quienes escuchan y ven las hazañas de los rebeldes que vencieron a Batista y se sepa que entre ellos ha brillado la valentía de un argentino.

A partir del triunfo de los guerrilleros en la Sierra, el Che comienza a convertirse en una leyenda transmitida por imágenes en cadena mundial para todo aquel con acceso a diarios, revistas, radios y televisores. Como uno de los primeros embajadores itinerantes de la joven revolución cubana, en

\footnotetext{
${ }^{2}$ En otra parte del mundo, tal vez haya que pensar en el grupo de estudiantes, neuróticos, artistas y delincuentes para quienes la lectura pública, en 1953, de Howl, de Allen Ginsberg constituyó un himno detrás del cual muchos se embarcaron en aventuras nómades, mortificaciones corporales y raptos de fascinación por producir incansablemente una escritura coral y vocal, colectiva o individual, espontánea o sofisticada, un arte de vivir y una moral. Los beatniks hicieron escribir a todos sus amigos y ladrones y dealers y amantes, en una furia escrituraria que no tiene precedentes ni fenómenos parecidos. Ricardo Piglia destaca, en los impulsos nómades del Che, la misma compartida configuración del mundo que va a derivar en el viaje contracultural de los beatniks (Piglia, 2005).
} 
palabras de Todd Gitlin "la primera revolución televisada de la historia" (1987), las imágenes catódicas y de la prensa cotidiana lo muestran en las escalerillas de los aviones, saludando a estadistas, ovacionado por multitudes: es ya un hombre público y está en boca del mundo entero.

Los intelectuales progresistas consideraron que Guevara reunía de manera ejemplar todos los ideales de su tiempo. El Che mantiene una frecuente y abundante correspondencia con "grandes hombres", con poetas que admira y le dedican sus libros y, cuando puede, se encuentra con lo más notable de la intelectualidad mundial, no sólo para escuchar sino también para ser escuchado, ya que participa en debates políticos, económicos, estéticos y de cualquier naturaleza. Es un polemista conspicuo y cultiva todas las modalidades del discurso agonístico.

Los más prestigiosos representantes de la intelectualidad escribieron admirativamente sobre él, le dedicaron canciones, versos, elegías y eso no sólo mientras duró el fervor revolucionario sino también después, incluso ahora. ${ }^{3}$ Incluso, en su elección del camino de soldado, el Che alcanzó la superación vital del viejo y presuntamente insalvable dilema entre las letras y las armas, actuando en perfecta coincidencia la dimensión de la palabra y la de la acción.

\section{Armas y letras}

Montañas de documentación revelan la obsesión del Che por la lectura. Empieza a leer y a tirar con pistola a los 5 años y no deja de hacer ambas cosas hasta su muerte. Lee a todas horas, especialmente cuando niño, en los momentos en que, afectado por el asma, debe permanecer en cama. A los 17 comienza a escribir en varios cuadernos escolares un Diccionario de filosofía (que continuó reescribiendo hasta el su incorporación al movimiento 26 de Julio) y un índice de lecturas que continuará hasta sus últimos momentos, en Bolivia, y que llevaba en una agenda de teléfonos, junto al fusil y las balas.

\footnotetext{
${ }^{3}$ En la antología Guevariana (2007) se recopilan textos de homenaje a Guevara, algunos escritos en ocasión de su muerte y otros, más recientes, donde las relecturas del Che continúan elogiando y reformulando sus significaciones. Mempo Giardinelli valora su ejemplaridad, José Saramago evoca la nostalgia de un presente al que la muerte de Guevara y el fracaso de su proyecto le han quitado esperanza al futuro y sentido al presente, Osvaldo Soriano lo ubica en la galería de los héroes americanos, Paco Ignacio Taibo II lo considera un santo laico, Manuel Vázquez Montalbán reivindica la moral y la solidaridad de la figura de Guevara y Heinrich Böll lo toma como ejemplo de fraternidad internacionalista. En todos los casos, se subraya la ejemplaridad.

En él se dieron, según Lezama Lima, la areteia, el sacrificio, el afán de holocausto. Dice Edmundo Desnoes del Che: "Hubo, siglos atrás, un hombre que nos soñó. Y aunque hoy no puede marcarse dónde termina cada yo y empieza el otro, digo más: vivió enfermo por nosotros". La culpa del sano que experimenta Desnoes, o el "anonadamiento" del que habla Rodolfo Walsh, es la que sienten los destinatarios del sacrificio, la mala conciencia de los seres imperfectos ante la perfección. Los que escriben se comparan con alguien que hacía bien todas las cosas (AAVV, 1968).
} 
Guevara detesta las ciudades; está a sus anchas en las zonas campesinas y premodernas, enseñando el amor por la lectura y la doctrina revolucionaria. ${ }^{4}$ Es un rasgo de arcaísmo que se opone a la celebración de la ciudad y al despoblamiento rural a escala mundial de ese período. En el Hombrito, en el Congo, en Bolivia, siempre dedica tiempo a la alfabetización. Las arengas del Che contienen siempre más que un memento mori, son casi una invitación a la muerte. Quienes lo acompañarán después serán los sobrevivientes de su célebre Pelotón suicida. Pombo cuenta cómo la enseñanza del Che era 'la' ordalía del recluta: Guevara enseñaba bajo el fuego de los aviones enemigos.

Es el jefe y la voz de mando que convierte en acción lo que ordena; además es quien trae la letra, como Prometeo el fuego, como salvación de los hombres. Quiere enseñarlo todo y lo hace, como parte del entrenamiento y de la vida cotidiana del foco. En decenas de fotos se lo ve enseñando en las pausas de la marcha. En Bolivia, por ejemplo, los guerrilleros estudiaron algo de quechua y se proponían seguir con el aymará.

Esa fe en la letra y el conocimiento, que lo acercará al ideal letrado de su tiempo, sobrevive a las transformaciones de la Grafosfera. Más que otros letrados de su tiempo, es Guevara quien difunde la necesidad de ilustración en nuevos soportes ya auditivos y visuales, como la televisión, que se volverá el medio hegemónico apenas después de su muerte. Poco tiempo antes de ser apresado y ya enfrentando serias dificultades, Guevara lamenta su situación. El 19 de septiembre de 1967 anota: "Signo de los tiempos: se me acabó la tinta" (208). Difícil no comparar este dato duro que lo obliga a detener la escritura con lo que les sucede a los personajes de la trilogía de Beckett, que pueden continuar escribiendo aun si han perdido sus cuadernos, sus lápices o no tienen ni siquiera manos, como el Innombrable. Dura constatación de las ventajas de la escritura de ficción sobre la de la 'realidad'. En el momento en que la situación se vuelve urgente, lo único que importa, escribirá Guevara, son los hechos. "Las palabras que no concuerdan con los hechos no tienen importancia", consigna el 25 de marzo de 1967 en su Diario de Bolivia (82).

Entre las posesiones más estimadas que cargaban los alzados, se destacaba siempre la pesada mochila conteniendo la biblioteca ambulante ${ }^{5}$ y los diarios que la mayoría de los rebeldes escribían durante la campaña. Escritor, orador, lector, maestro, especialista en cultivar almas sin letras, en escribir

\footnotetext{
${ }^{4}$ Una tarea que ya había enfrentado Cristo,como Mateo describe: "las gentes se admiraban de su doctrina; [de Jesús] porque les enseñaba como quien tiene autoridad y no como los escribas” (Mateo 7, 28-29).

${ }^{5}$ Durante la campaña en la Sierra Maestra, Guevara, estratega de las redes, logra establecer una logística que permite subir a la montaña libros de Martí y poemarios de José María Heredia, Gertrudis de Avellaneda, Gabriel de la Concepción, Rubén Darío, para alternar con la biografía de Goethe, de Emil Ludwig, que está leyendo, según puede verse en una foto en la que el Che se encuentra dentro de un bohío, recostado y cubierto por una manta y con un enorme puro en la boca.
} 
en los márgenes de su poco tiempo, en soportes precarios: libretitas, cuadernos, libros en cuyos espacios libres anota minuciosamente su escritura de comentador y de refutador.

Aunque se encuentra extendida de manera brutal su identificación con Jesucristo, su devoción por la letra y su sacralidad está más alentada por el furor del Mahoma que reprocha a los infieles su desconfianza en las escrituras divinas y llama a luchar hasta la muerte para que se respeten. Sin embargo, en Guevara, la teoría y la praxis están imbricadas. Por eso señala en 'Guerra de guerrillas: un método' "No hay oficio ni profesión que se pueda aprender solamente en los libros de texto. La lucha, en este caso, es la gran maestra" (1963: 24).

Guevara desarrolla su doble pasión por las letras y por las armas, no sólo en privado sino en público y en tiempo real, por todos los medios, los arcaicos, los modernos, en un mundo en el que, como describe Margaret Mead en 1969 "todos los pueblos del mundo forman parte de una red de intercomunicación con bases electrónicas" (1971). Su voz y su escritura acortan las distancias al instante y esa intensificación de lo oral también se corresponde con la intensificación de lo visual, con la repetición de su presencia en todas partes y a todas horas ${ }^{6}$. Es un nodo privilegiado en todas las direcciones topológicas, tanto terrenales como virtuales y también un experto tecnólogo de la palabra, la primera pieza o eslabón de cualquier red. Se ubica en el cruce de las relaciones entre oralidad y escritura justamente en el pasaje de la cultura del libro a la naciente Videosfera que lo incluye como uno de sus objetos privilegiados.

Ese mundo posee tanto los elementos de reproducción a gran escala como una memoria cultural en la que conviven elementos orales y letrados que convergen en su figura del Che. Esos elementos que constituyen la materia prima del héroe y el santo modernos. Lo mediático, incipiente pero portentoso en la coyuntura del Che y de la revolución cubana, condensado en una serie de imágenes verdaderamente inolvidables, puede pensarse como un aspecto configurante de lo heroico y de la santidad. Las imágenes y el alto impacto de las noticias cubanas amplificaron extraordinariamente lo que las culturas anteriores, que todavía carecían de elementos para producir escenas globales a escala planetaria, denominaban fama. La vida del Che ya estaba, si se quiere, disponible para el ejemplo, la biografía, el canto propagandístico, la identificación y la admiración por el héroe. Para un mundo no enteramente alfabetizado o, por el contrario, extraordinariamente letrado, el Che en acción representa lo situacional y lo agonístico de lo oral, eso que también definirá las muchas referencias de sus contemporáneos al carácter arrollador de su querida presencia.

\footnotetext{
${ }^{6}$ Es irónico que, más allá de los enigmas que todavía permanecen, su muerte se deba a la fallas de los sistemas de redes, a la incomunicación, a la pérdida de contactos con su red urbana, a la rotura de la radio. Pierde contacto incluso con sus propios hombres. Todo eso acontece precisamente en los momentos en que estaba desarrollándose una tecnología que revolucionaría las comunicaciones y las posibilidades de funcionar en red en una escala donde la voluntad no necesariamente juega ningún papel.
} 
La presencia, por otra parte, es oral/aural por definición. Evocando el impacto que le provocó oír por radio la entrevista de Masetti al Che, dice Ciro Bustos: “Lo que me impresionó al escuchar al Che no fue su discurso político ni su mensaje revolucionario, que ni siquiera lo había, ya que la radio porteña centraba la cuestión en su condición de argentino metido en guerras de ideas casi bolivarianas. La conexión se produjo en primer lugar con la voz, que no era la voz engolada o doctoral de un político o demagogo profesional. Era una voz que podía salir de la garganta de un hermano o amigo mío, sin ninguna petulancia, en una tranquila conversación de café. (... ) El programa terminó con el reportaje a Fidel Castro, que constituía el plato fuerte. Pero a mí me quedó resonando la voz del Che, esa voz que se oía por primera vez, la voz de la verdad...” (2007: 37-38).

La tradición heroica de la cultura oral primaria y de la cultura escolarizada temprana está relacionada con el estilo de vida agonístico, pero se explica mejor y de manera más contundente desde el punto de vista de las necesidades de los procesos intelectuales orales. De acuerdo con Walter Ong, la memoria oral funciona eficazmente con los grandes personajes cuyas proezas son gloriosas, memorables y, por lo común, públicas. Las personalidades incoloras no pueden sobrevivir a la mnemotécnica oral. A fin de asegurar el peso y la calidad de notables, las figuras heroicas tienden a ser genéricas: el sabio Néstor, el aguerrido Aquiles, el astuto Odiseo. Resulta más fácil acordarse del Cíclope que de un monstruo de dos ojos; o del Cancerbero que de un perro ordinario de una cabeza. Por otra parte, la fuerza de la palabra oral para interiorizar se relaciona de una manera especial con lo sagrado, con las preocupaciones fundamentales de la existencia. En la mayoría de las religiones, la palabra hablada es parte integral de la vida ritual y devota. Paul Zumthor prefiere el término 'vocalidad' para expresar la historicidad de la voz: su empleo. En el texto pronunciado, cuando se lo enuncia, la voz trasmuta en ícono el signo simbólico proporcionado por el lenguaje; tiende a despojar al signo de todo lo que tiene de arbitrario; lo motiva con la presencia de ese cuerpo del que emana (Zumthor, 1995: 25). Pensemos en la magnitud de esta dimensión aural en un mundo de oralidad secundaria que además recupera la potencia de lo visual unida a la impresión que causó en el mundo un acontecimiento extraordinario como lo fue la Revolución Cubana.

Para comprender cómo queda soldado al pasado y al presente, también hay que considerar los aspectos presentes y persistentes del heroísmo, tanto en las culturas orales -lo que resulta lógico y natural- como en las hiperletradas. Eric Hobsbawm (2001) analiza la gravitación de los diversos mitos sobre el bandolerismo, y no hace falta repasar mucho epopeyas y ciclos legendarios de culturas orales para ver que hay en casi todos los relatos significaciones afines. 


\section{La secularización irrealizada}

Una de las taquigrafías simbólicas más eficaces conecta al Che con una versión de Cristo y hasta con un dispositivo Marx/Cristo, lo que parece señalar las cuentas pendientes del estado de la cuestión sobre la secularización que, como afirma acertadamente Giacomo Marramao (1998), es una de las expresiones clave del debate político, ético y filosófico contemporáneo. Ya en 1922 Carl Schmitt señalaba: "Todos los conceptos más importantes de la doctrina moderna del Estado son conceptos teológicos secularizados" (21). Por su parte, para Hannah Arendt, la secularización como acontecimiento histórico tangible no significa otra cosa que separación de Iglesia y Estado, de religión y política, y ello, desde un punto de vista político, implica una vuelta a la primitiva actitud cristiana ("dad al César lo que es del César y a Dios lo que es de Dios”), más que la desaparición de la fe en la trascendencia o un nuevo interés enfático por las cosas de este mundo

Karl Löwith desarrolla la hipótesis de que la filosofía moderna de la historia se formula como "secularización de la escatología cristiana”, es decir, como transposición del eschaton del plano de la trascendencia al de la inmanencia histórica -lo que Marramao denomina "las raíces mesiánicas del futurismo"-. En sus líneas esenciales, la afirmación principal de la tesis de Löwith es que el pensamiento supuestamente secularizado, centrado en la idea global y universalista del progreso, representa el resultado de una secularización de la teología de la historia de orientación cristiana. Se trata, dicho resumidamente, de la sustitución de la Providencia por el progreso, de Dios por el hombre como sujeto absoluto de la historia. En este proceso, los atributos teológicos se rompen ante la dimensión de la trascendencia para ser radicalmente mundanizados y transferidos al dinamismo histórico inmanente. Y sin embargo, precisamente por la amplitud y plenitud de la secularización tendría un efecto paradójico e imprevisto: la absolutización y sacralización del mundo histórico. La concepción del tiempo futurocéntrica es incomprensible sin la matriz judeocristiana de la modernidad: la moderna filosofía de la historia tiene su origen en la fe bíblica y en un cumplimiento futuro, y termina con la secularización de su modelo escatológico.

En su carta a Quijano, de 1964, conocida como "El socialismo y el hombre en Cuba", en la que desarrolla su concepción del hombre nuevo, Guevara escribe: "Déjeme decirle, a riesgo de parecer ridículo, que el revolucionario verdadero está guiado por grandes sentimientos de amor. Es imposible pensar en un revolucionario auténtico sin esta cualidad. Quizás sea uno de los grandes dramas del dirigente; éste debe unir a un espíritu apasionado una mente fría y tomar decisiones dolorosas sin que se contraiga un músculo. Nuestros revolucionarios de vanguardia tienen que idealizar ese amor a los pueblos, a las causas más sagradas y hacerlo único, indivisible. No pueden descender con su pequeña dosis de cariño cotidiano hacia los lugares donde el hombre común lo ejercita” (1970: 382). Guevara 
ejemplifica la secularización del modelo escatológico, en tanto que asume el mesianismo y la zona del credo del amor predicada por Cristo.

De modo que las significaciones crísticas, si bien se hacen visibles claramente en la iconografía que rodea al Che, no se agotan en ella. Unidas a los componentes heroicos, agonísticos y tradicionalistas de las culturas orales, explican su presencia en la cultura del ciberespacio, donde, su figura es objeto de innumerables discursos y representaciones. Una de sus características suele ser, por ejemplo, que la opinión o valoración no se fundamente en el cuerpo de conocimientos existentes. Pero casi no hay discurso o imagen sobre el Che que no necesite pasar y repasar por esa asociación crística, lo que permite constatar que el lazo no es para nada idiosincrático sino fundado colectivamente por miembros de una comunidad de límites inciertos y topología no cartografiada por el momento. Iconográficamente sorprendente, esa asociación supera los límites de la mera imagen.

En su libro Il mito del Che, Alberto Filippi analiza desde una perspectiva histórica, política e iconográfica el proceso de cristianización de Guevara y el de la construcción del mito mundial que permite atribuir significaciones siempre presentes al Che, "eroe piú famoso e controverso del secololo scorso" (2007). Ese proceso de cristianización coincide con la aparición de una nueva camada de católicos organizada en torno a la Teología de la Liberación, que va por el nudo de Guevara (y Camilo Torres, claro) a Jesús: "De manera simbólica, podría decirse que la corriente cristiana radical nació en enero de 1959 en el momento en que Fidel Castro, el Che Guevara y sus camaradas marcharon hacia La Habana, mientras en Roma Juan XXIII emitía su primera llamada a la celebración del concilio”, como sostiene Malcolm Lowy (1999: 59).

Podría objetarse, con respecto a la asociación Che-Cristo, cómo se hace en los casos en los que se destacan la crueldad del asesino Guevara, culpable de no acatar el mandamiento "No matarás". Pero esta objeción sólo puede surgir olvidando lo que hace decir a Cristo a los evangelistas Mateo y Lucas: "No penséis que he venido para traer paz, sino espada. Porque he venido para enfrentar al hombre contra su padre, a la hija contra su madre, a la nuera contra su suegra" (Mateo 10, 34-35). O sin recordar el "ardor de verdaderos cristianos por defender al verdadero Dios con la espada, el fuego y la sangre se presenta constantemente tanto en la historia del cristianismo oriental como occidental" (Castoriadis, 1997: 28). O las conmovedoras reflexiones de Kierkegaard, que nos recuerda el heroísmo de Abraham, capaz de matar a su hijo por la fe y la obediencia prometida a su Dios y sin jamás quejarse. ${ }^{7}$

Para Jorge Castañeda, uno de sus incontables biógrafos, el "Che cristianizado" fue producto de un error del ejército boliviano, que al limpiar y emprolijar el cadáver del Che para corroborar que ése era el

\footnotetext{
${ }^{7}$ No cabe duda de que el cuerpo revolucionario hereda algunos aspectos de la figura del soberano. En el Che puede leerse el lugar de la encarnación, una piel saturada, tanto por una economía de los principios como de la muerte misma. Debo esta sugerencia a Julio Ramos, a quien agradezco.
} 
hombre, el Guevara al que buscaban, transformaron "al revolucionario resignado y acorralado, al indigente de la quebrada del Yuro, vencido con todas las de la ley, envuelto en trapos y con la cara ensombrecida por la furia y la derrota, en la imagen crística de la vida que sigue a la muerte" (1997: 17). Esa imagen captada en la inolvidable fotografía de Freddy Alborta, que unió el mundo en un instante y se adueñó de parte del imaginario universal.

¿Sus propios enemigos desataron la cristianización a través del dispositivo de rostrificación o llevaron el proceso a la culminación absoluta, acentuando una deriva que ya estaba disponible? "El rostro es Cristo", el año cero de la máquina de rostridad, nos recuerdan Deleuze y Guattari (2000: 180-187). No sé si tendrán o no razón, ni si sus afirmaciones son válidas para todas las culturas. ${ }^{8}$ Sí son válidas para todas aquellas que presuponen a Cristo. Y no hace falta ser católico para sumarse a la notación que divide los tiempos en antes y después de Cristo, como los romanos lo hacían a partir de la fundación de Roma. Del agenciamiento crístico, tanto producido por el Che como por la cultura que lo asimila se pueden consignar la ejemplaridad, el peregrinaje continuo, la búsqueda de la sanación de los sufrimientos humanos, el ecumenismo, el redentorismo, la buena nueva, la apuesta a la futuridad, la pasión, la prédica y el reclutamiento, el sacrificio, la muerte y casi todas las estaciones de una vida llena de pasiones.

Pero dado que para viajar en el espacio hay que viajar en el tiempo, en el trayecto sorprende hasta qué punto y explícitamente, se produce en pensadores declaradamente ateos un agenciamiento cristianismo-marxismo, que con el Che adquiere dimensiones más densas y agonísticas. En nombre de la era común, el internacionalismo o la palingenesia del hombre a través de la revolución, un futuro ideal siempre será tierra prometida o paraíso.

En 1993 y con el propósito de analizar su presente, Jacques Derrida se pregunta por qué, si en 1959 Maurice Blanchot ya había escrito "La fin de la philosophie" recién treinta años después el mundo retoma el debate sobre el fin de la historia. Por qué, si las reflexiones sobre el fin del hombre y el fin de la historia eran el pan cotidiano de él y sus colegas en los años cincuenta. Tal vez sea una nueva demostración del nacionalismo o el europeísmo de muchos pensadores franceses. En otros sitios, contrariamente 1959 fue una fecha inaugural para la historia. Entre los espectros de Marx y de Derrida, parece faltar el más ostensible. Y sin embargo, en los ejes de la reflexión derrideana en torno a Marx y su legado, resuenan con fuerza los tópicos que atraviesan las significaciones de Ernesto Che Guevara, en particular los que se vinculan con el ejemplo y la ejemplaridad. "Lo ejemplar se abre a la singularidad de lo excepcional; el ejemplo siempre va más allá de sí mismo. Es, siempre, para otros. En ese sentido, abre una cuestión testamentaria que está abierta a todas las temporalidades” (Derrida, 1995).

\footnotetext{
8 "Moisés cubrió su rostro por temor a Dios... En cambio Cristo, es nuestro único ingreso a ese rostro: La auténtica faz de Dios sólo podemos verla en la persona de su Hijo unigénito, el Verbo divino, aquel que dijo: 'El que me ha visto a mí, ha visto al Padre"” (Jn. 14: 9)
} 
Tal vez es raro predicar de Marx lo que justamente insiste en caracterizar a Guevara y, superlativamente, a Cristo. Dice Derrida del marxismo lo que se podría decir del Che en la versión de la secularización irrealizada que da forma a sus argumentos: "Por su carácter internacional, el marxismo inaugura un espacio que amenaza todos los estados" (1995). Y cuenta Régis Debray que Louis Althusser sostuvo que había adherido al marxismo a causa de su catolicismo (el del marxismo), puesto que había encontrado en el comunismo un sentido análogo de lo universal (1996: 33). En este punto, parece tener razón Löwith: la moderna filosofía de la historia (en la que se inscriben claramente los argumentos derrideanos) hunde sus raíces en la escatología judeocristiana y crea un mesianismo específicamente occidental.

Por otra parte, si es cierto que, como dice Derrida, refiriéndose al legado de Marx: "No hace falta ser marxista o comunista para rendirse a la evidencia de que compartimos un legado. Habitamos todos un mundo, algunos lo llamarán una cultura que conserva, de manera directamente visible o no, en una profundidad incalculable, la marca de ese legado" (1995: 36), entonces, si nuestra cultura presupone a Marx, a quien el propio Althusser confesó no haber leído por completo, ¿cómo no presupondría a Cristo? ¿Quiénes son los espectros?

En cuanto al propio Che, su presuposición de Cristo es absoluta, como lo es también su fascinación por los héroes. Podría decirse que hasta se presupone como un Cristo más valiente. En lugar de decir "eli eli lama sabachtani”, como el Cristo de la Cruz, se recita "Perdóname Señor: qué poco he muerto", un verso de Vallejo de su poema "Ágape". Como un ritornelo, Guevara lee y recita poemas que había transcripto de su puño y letra en su cuaderno, que llevaba cuando lo apresaron en Bolivia. Era su antología personal, compuesto por sus poetas favoritos (Pablo Neruda, León Felipe y Nicolás Guillén, a quienes conoció personalmente, y César Vallejo). Muchos poemas tenían ecos de ese Cristo o dios padre españolísimo y guerrero que llenó la lírica castellana de todas partes con la resonancia fuerte de la guerra civil $^{9}$ y que sin dudas contribuyó a presuponer el nudo Cristo-Che. Muchos testimonios lo evocan recitando casi a modo de arengas esas poesías. Textos que tienen todo que ver con lo que él mismo evoca, como el fragmento de León Felipe: “¡Aquí están las cartas boca arriba! El Guerrero y el Santo. ¿Por quién apuestas tú?"”

Entre esos papeles se encuentra el siguiente poema:

Cristo, te amo

No porque bajaste de una estrella

Sino porque me descubriste

\footnotetext{
${ }^{9}$ En abril de 1961, Guevara ofrece al General español Líster, héroe de la poesía de Machado, ponerse a sus órdenes para derrocar a Franco. Le recita al propio Líster en La Habana, mientras le ofrece su arma, los versos que Antonio Machado había dedicado al General: "si mi pluma valiera tu pistola, de general contento moriría” (Gilman, 2010).
} 
que el hombre tiene sangre,

lágrimas, congojas...

llaves herramientas!

Para abrir las puertas cerradas de la luz

Sí, tú nos enseñaste que el hombre es dios...

Un pobre dios crucificado como tú

Y aquel que está a tu izquierda en el gólgota

El mal ladrón

También es un dios! 10

Estas líneas, pertenecientes a un poema de León Felipe, se le atribuyeron al propio Che durante los confusos momentos posteriores a su ejecución. Actualmente, se le siguen atribuyendo en muchos sitios web.

La hazaña guerrera, la mortificación, la penuria autoinflingida hace héroes y santos. Guevara conecta a Cristo con Martí, a Marx con El Quijote, con los olímpicos de Píndaro, con San Martín, con Bolívar, entre otros; en la serie de los pescadores de hombres, los que comandan batallones, los héroes, los santos, los que crean las gestas que otros cantan o escriben. Y se es una cosa o la otra según qué institución o qué “países mentales” glorifican o canonizan. ¿Cuánto puede haber de triunfo sobre sí misma en la peculiar tarea religiosa de Teresa de Calcuta? ¿Cuánto afán de mortificación hace falta para ser santo o héroe? Ya lo pensaba Rama entonces, cuando afirmaba: "La heroicidad produce el mismo deslumbramiento y el mismo pánico que la santidad, porque está hecha de su misma atroz desmesura y genera entre el multitudinario coro de quienes presenciamos la tragedia, la conciencia terrible de ser destinatarios del sacrificio".

Los Evangelios se concentran en desarrollar la biografía de un hombre excepcional. El Antiguo Testamento, que establece la idea de un Dios a imagen y semejanza del hombre, tiende más bien al conjunto de las biografías extraordinarias, casi nunca ejemplares. La vida de Guevara se presta inusualmente a la pasión de los biógrafos. Se han escrito y se siguen escribiendo en cantidad las vidas del Che. Tanto discursos letrados y eruditos, biografías escritas con todas las reglas del género y de la edición junto con producciones no grafas, que en la red de redes se multiplican a diario, consolidan la leyenda de una vida predestinada desde la infancia que lo aproxima todavía más al héroe, al santo laico, o a un nómade redentorista que venía a reformular un mensaje cristiano en términos de guerra santa por los hombres y que murió tratando de hacer realidad ese futuro del que era su principal evangelista. Puede que para los bolivianos, aunque ciertamente no sólo para ellos, sea esa significación la que lo haya convertido en San Ernesto de la Higuera.

\footnotetext{
${ }^{10}$ Recogido en El cuaderno verde, editado por Taibo II (2007), perteneciente al poema ‘La gran aventura’, de León Felipe.
} 


\section{Bibliografía}

AAVV. Casa de las Américas 46 (enero-febrero 1968)

Bustos, Ciro (2007). El Che quiere verte. La historia jamás contada del Che. Buenos Aires: Vergara.

Castañeda, Jorge (1997). La vida en rojo. Una biografía del Che Guevara. Madrid: Alfaguara.

Castoriadis, Cornelius (1997). El mundo fragmentado... Buenos Aires: Altamira.

Debray, Regis (1996). Loués soient nôtres seigneurs. Paris: Gallimard.

Deleuze, Gilles; Guattari, Felix (2000). Mil mesetas. Capitalismo y esquizofrenia. Valencia: Pre-Textos.

Derrida, Jacques (1995). Espectros de Marx. Madrid: Trotta.

Filippi, Alberto (2007). Il mito del Che. Turín: Einaudi.

Filippi, Alberto y Paolo Collo, comps. (2007). Guevariana. Raconte e storie sulChe. Turín: Einaudi.

Gilman, Claudia. (2003). Entre la pluma y el fusil. Debates y dilemas del escritor revolucionario en América Latina. Buenos Aires: Siglo XXI Editora.

Gilman, Claudia. "Maneras de decir: el canto de la acción. El Che Guevara, polígrafo salvaje”. El interpretador 36 (2010).

Gitlin, Todd (1987). The Sixties. Years of Hope, Days of rage. NY: Bantam Books.

Guevara, Ernesto (1960). La guerra de guerrillas. La Habana: Talleres Tipográficos del I.N.R.A.

Guevara, Ernesto [1967] Diario de Bolivia .

Guevara, Ernesto. [1965] "El socialismo y el hombre en Cuba”. Obras 1957-1967. La Habana: Casa de las Américas: 366-384.

Hobsbawm, Eric (1995). Historia del siglo XX: 1914-1991. Buenos Aires: Crítica- Grijalbo Mondadori.

Hobsbawm, Eric (2001). Bandidos. Barcelona: Crítica.

Jameson, Frederic.[1984] (1997). Periodizar los 60. Córdoba: Alción editora.

Marramao, Giacomo (1998). Cielo y tierra. Genealogía de la secularización. Paidós: Buenos Aires.

Mead, Margaret (1971): Cultura y compromiso. Estudio sobre la ruptura generacional, Buenos Aires: Granica. 
Latour, Bruno (2007). Nunca fuimos modernos. Ensayo de antropología simétrica. Buenos Aires: Siglo XXI. (Publicación original 1991).

Lowy, Malcolm (1999). Guerra de dioses. Religión y política en América Latina. México: Siglo XXI.

Ong, Walter (1982). Orality and Literacy. London-New York: Methuen.

Piglia, Ricardo (2005). "Ernesto Guevara, rastros de lectura". El último lector. Barcelona: Anagrama. 103-138.

Schmitt, Carl (1922). Politische Theologie. Vier Kapitel zur Lehre von der Souveranität. Munich/Lepzig: Duncker \& Humblot.

Taibo II, Paco Ignacio (2007). El cuaderno verde del Che. México: Seix Barral.

Zumthor, Paul (1989). La letra y la voz de la literatura medieval. Madrid: Cátedra. 